УДК 378.016:78-051:37.015.31
DOI https://doi.org/10.31723/2524-0447-2020-30-1-23

\author{
Гун Вейді \\ ORCID: 0000-0002-3376-0239 \\ аспірантка кафедри образотворчого мистецтва, \\ музикознавства та культурології \\ Сумського державного педагогічного університету імені А. С. Макаренка \\ akosorich@gmail.com
}

\title{
ОСОБЛИВОСТІ ПІДГОТОВКИ ДИРИГЕНТІВ ХОРУ: ТЕОРЕТИЧНІ ТА ПРАКТИЧНІ АСПЕКТИ ПРОБЛЕМИ
}

\begin{abstract}
Мета роботи - визначити особливості підготовки диригентів хору в контексті музикознавчого дискурсу. Методологія дослідження - для досягнення мети в роботі використано комплекс методів, а саме: аналітичний - для обробки й аналізу наукових літературних-джерел за темою дослідження вітчизняних і закордонних науковців із культурології, мистецтвознавства, психофізіологів, які висвітлюють теорії та концепції щодо підготовки диригентів хору та музичних колективів; узагальнення що дало змогу визначити поняттєвий апарат статті, висвітлити концептуальні положення та результати; системно-структурний - забезпечив розроблення структурних складників досліджуваного явища. Наукова новизна полягає у визначені ролі хорового диригента в музичному мистецтві, а саме: визначено стан вивченості означеної проблеми, обгрунтовано наукові уявлення про специфіку діяльності хорового диригента; розкрито психофізіологічні аспекти означеного процесу. Висновки. Сучасний процес підготовки хорового диригента має бути спрямований на фахове зростання особистості, що пов'язане з вивченням впливу психофізіологічних важелів на процес накопичення практичного ресурсу. Творча потреба диригента в естетичному результаті є основним джерелом мистецької енергії, що спонукає його до творчого самовираження, яке віддзеркалює внутрішню інтерпретацію музичного твору. Музично-диригентський вплив на людину відбувається завдяки таким засобам: від елементарних ідеомоторних дій, пов'язаних із керуванням сенсорних систем (відчуттів) під час виконання музичного твору (акустичні, вібраційні, фонетичні тощо), до багатогранних емоційно-образних навіювань, що за своєю суттю відповідають режисерській роботі. Отже, у пропонованій статті виявлено стан розробленості проблеми формування диригентської майстерності, означено перспективні питання для подальшого наукового дослідження.
\end{abstract}

Ключові слова: диригент, фахова підготовка, хормейстерсько-диригентська теорія підготовки, психофізіологія.

Veydi Gun, Postgraduate Student at the Department of Fine Arts, Musicology and Cultural Studies of the Sumy State Pedagogical University named after A. S. Makarenko

Features of the training of choir conductors: theoretical and practical aspects of the problem

Research objective is to determine the peculiarities of the choir conductors training in the context of musicological discourse. The methodology - a set of methods that complement each other and are interrelated: analytical - for processing and analysis of scientific literature-sources on the topic of research of national and foreign cultural science scholars, psychophysiologists, who cover the theories of conception. on the training of choir conductors and bands; generalization - which made it possible to define the conceptual apparatus of the article and to clarify conceptual provisions and results; systemic-structural - provided the development of structural components of the phenomenon under study. Scientific novelty - consists in the defined role of the choral conductor in the musical art, namely: the state of study of the identified problem is determined, the scientific ideas about the specificity of the choral conductor activity are substantiated; psychophysiological aspects of the identified process are revealed. Conclusions. The modern process of preparing a choral conductor should be aimed at professional growth of the personality, which is associated with the study of influential psychophysiological levers on the process of accumulating a practical resource. The conductor's creative need for an aesthetic result, the main source of artistic energy, encourages him to express himself creatively, which reflects the internal interpretation of a musical work. Musical and conductor influence on a person occurs thanks to such means: from elementary ideomotor actions associated with the management of sensory systems (sensations) in the performance of a musical work (acoustic, vibrational, phonetic, etc.), to multifaceted emotionally-shaped suggestions, in its the essence of the relevant directorial work.

Key words: conductor, professional training, choirmaster-conductor theory of training, psychophysiology. 
Вейди Гун, аспирантка кафедры изобразительного искусства, музыковедения и культурологии Сумского государственного педагогического университета имени А. С. Макаренко

Особенности подготовки дирижеров хора: теоретические и практические аспекты проблемы

Цель работы - определить особенности подготовки дирижеров хора в контексте музыковедческого дискурса. Методология исследования - для достижения цели в работе использован комплекс методов, которые дополняют друг друга и взаимосвязаны: аналитический - для обработки и анализа научных литературных источников по теме исследования отечественных и зарубежных ученых в области культурологии и искусствоведения, психофизиологов, освещающих теории и концепции по подготовке дирижсеров хора и музыкальных коллективов; обобщение - что позволило определить понятийный аппарат статьи, представить концептуальные положения и результаты; системно-структурный - обеспечил разработку структурных составляющих изучаемого явления. Научная новизна заключается в определении роли хорового дирижера в музыкальном искусстве, а именно: определено состояние изученности данной проблемы, обосновано научное представление о специфике деятельности хорового дирижера; раскрыты некоторые психофизиологические аспекты указанного процесса. Выводы. Современный процесс подготовки хорового дирижера должен быть направлен на профессиональный рост личности, что связано с изучением влияния психофизиологических рычагов на процесс накопления практического ресурса. Творческая потребность дирижера в эстетическом результате является основным источником художественной энергии, побуждает его к творческому самовыражению, которое отражает внутреннюю интерпретацию музыкального произведения. Музыкально-дирижкерское влияние на человека оказывается благодаря таким средствам: от элементарных идеомоторных действий, связанных с управлением сенсорных систем (ошущений) при исполнении музыкального произведения (акустические, вибрационные, фонетические и другик), до многогранных эмоционально-образных внушений, по своей сути соответствующих режиссерской работе.

Ключевые слова: дирижер, профессиональная подготовка, хормейстерско-дирижерская теория подготовки, психофизиология.

Актуальність теми дослідження. Наукова думка в галузі мистецтва на сучасному етапі розвитку характеризує розв'язанням проблеми ефективного методичного забезпечення підготовки диригентів, саме ця проблема протягом кількох століть є ключовою для мистецької науки та музичного виховання. В історичному аспекті мистецька наука закумулювала великий досвід теоретичних та практичних знань під час підготовки диригентів та музикантів, але водночас кожна епоха характеризується все вищими вимогами до музикантів, зокрема й до диригентів, на перших етапах підготовки.

Фундаментально-теоретичні аспекти підготовки диригентів висвітлені в роботах таких науковців, як: Л. Браунайс, С. Кареда, А. Пярт (2014р.); А. Єфименко (2011р.); Л. Бутенко (2009 р.); С. Гоменюк (2007 р.); Н. Герасимова-Персидська (2003, 2005, 2006 рр.); Є. Дубинець (1999 р.); Г. Дмитревська (1957, 1965, 1968 рр.) $[1 ; 2 ; 3 ; 4 ; 5 ; 6 ; 7 ; 8 ; 9 ; 10 ; 12]$.

Аналіз літературних джерел, які відбивають проблему підготовки диригентів та митців у галузі музики, дає підгрунтя для формування висновку щодо неповноти висвітлення проблеми наукового дослідження, присвяченого підготовці диригентів в мистецькоосвітньому просторі України, що й зумовило вибір теми нашої статті.

Мета дослідження - визначити особливості підготовки диригентів хору в контексті музикознавчого дискурсу.

Наукова новизна полягає у визначені ролі хорового диригента в музичному мистецтві, а саме: визначено стан вивченості означеної проблеми, обгрунтовано наукові уявлення про специфіку діяльності хорового диригента; розкрито психофізіологічні аспекти означеного процесу.

Виклад основного матеріалу. Системний аналіз сучасного хорового мистецтва, сприйняття й осмислення витворів хорового мистецтва є основою, що дає змогу оцінити диригентську діяльності. Зазначимо, що хорове мистецтво поєднує в собі декілька суперечностей: між композитором та виконавцем, між композитором та диригентом. Інновації в діяльності композитора вступають у конфлікт із константами хорових стереотипів, що формує основні непорозуміння під час виконання сучасних хорових творів та відмову від їх виконання.

Основі вектори підготовки диригента такі: техніка диригування, яка включає в себе функціональні можливості руки (амплітуда та динаміка рухів, диригентський апарат); ознайомлення із твором, його аналіз (визначення мелодії і поліфонії та відбиття їх у партитурі); організація роботи хором (спілкування з хором: індивідуально-колективний метод); виконання твору як цілісного музичного явища [2].

Аналіз навчальних програм зі спеціальності «Хорове диригування» дозволив виявити, що фундаментальні навички майбутнього диригента формуються підчас занять із хорового 
диригування (індивідуальна форма навчання). Фахова підготовка організована так, що студент знайомиться з різними музичними творами за складністю та стилями, опановує їх. Набуті навички закріплюються під час виробничої практики й на заняттях у хоровому класі [13].

Професія диригента багатогранна, вона включає в себе не тільки складові елементи музичного мистецтва, а й психолого-педагогічні аспекти (різноманітне мислення із творчими аспектами, контроль та керування колективом), соціальні (спілкування з колективом, індивідуумами), психофізіологічні (кодування й обробка інформації з утворенням різних образів), вербальні та невербальні, біомеханічні (адекватна рухова активність, яка віддзеркалює диригентський апарат рухів).

Традиційна практика підготовки керівника хорового колективу поряд із накопиченим практичним досвідом спирається на наукові дослідження з різних галузей суміжних наук, пов'язаних із розвитком і діяльністю рухового апарату (рухові можливості верхніх кінцівок і організація просторового уявлення про рухові траєкторії) людини, зокрема: системної фізіології, психофізіології, біофізики та біомеханіки з елементами кінематики, акустики, педагогіки тощо, що забезпечує накопичення об'єктивної наукової інформації для підготовки диригента. Сучасне суспільство, яке характеризується як інформаційно-кібернетичне, має перспективні можливості новітнього бачення проблеми підготовки диригентів, відкриває нові грані як ендогенного, так і екзогенного характеру, що мають можливість впливати на процес підготовки керівника хорового колективу.

Диригент-керівник у сучасному суспільстві - поліфункціональна професія, що забезпечується симбіозом музиканта, організатора, психолога-педагога, митця, який потребує індивідуального бачення музичного твору, об’єднання творчих постатей в організований колектив; контролю процесу виконання музичного твору, що супроводжується диференціальною увагою та підходом; корегування акту виконання музичного твору; різнопланової комунікабельності. Професія диригента найскладніша з мистецьких видів діяльності, дуже відповідальна. Диригент несе особисту відповідальність перед колективом, адже хоровий колектив виконавців - це його особистий музичний інструмент, який складається зі співаків, які характеризуються індивідуальністю. Основне завдання диригента - це повести за собою творчий колектив, але водночас він повинен розуміти свою відповідальність перед суспільством за колектив і за себе. Провідна функція диригента - визначити індивідуальну траєкторію кожного виконавця, щоб музичний твір під час виконання цілком відповідав творчому задуму композитора, викликав відповідні образи й емоції. Мистецтво диригента полягає в індивідуально-творчій інтерпретації музичного твору, яку він доносить кожному учаснику хору за допомогою міміки, жестів і вступного слова перед репетиціями та виступом.

Ортодоксальний підхід в підготовці та розвитку професійної майстерності диригента базується на емпіричній методиці сприйняття виконавського процесу й орієнтує його на взаємозв'язок і взаємодію з м'язово-нервовою системою, результатом якої є біоакустичний звукоутворювальний ефект хорового звучання.

Диригування - це специфічний переклад музичного твору мовою рухів (жестів), емоцій та міміки, тобто трансформація звукового образу в зорово-руховий, що забезпечує відповідне керування хоровим колективом. Диригентська мова (диригентський апарат) базується на загальній та специфічній асоціації звучання музичного твору, що робить його мову доступною та зрозумілою як для митців професіоналів, так і для учасників самодіяльної творчості, навіть для слухачів без музичної освіти [14].

Творча потреба диригента в естетичному результаті є основним джерелом мистецької енергії, що спонукає його до творчого самовираження, яке віддзеркалює внутрішню інтерпретацію музичного твору.

Музично-диригентський вплив на людину відбувається завдяки таким засобам: від елементарних ідеомоторних дій, пов'язаних із керуванням сенсорних систем (відчуттів) під час виконання музичного твору (акустичні, вібраційні, фонетичні тощо), до багатогранних емоційно-образних навіювань, що за своєю суттю відповідають режисерській роботі.

Творча особистість диригента-хормейстера виражає свій внутрішній світогляд через музику, що перетворює нотні знаки на папері на образи, надає їй «силу життя» або «друге народження». Це відбувається не лише як результат фізичної взаємодії виконавців і диригента, але і як наслідок творчого діалогу між музичним твором та постаттю диригента. У сучасному мистецькому просторі виконавців поділяють на дві протилежні групи: «виконавці» й «інтерпретатори». Таке розмежування творчих позицій є помилковим і базується на нерозумінні самих принципів, які є основою музичної діяльності диригента. 
Музика не продається в магазині разом із нотами чи папером, що містить ноти. Не можна мислити формальними ознаками щодо музичних творів, проводити паралель між зовнішньою формою музики і мистецько-художнім образом, адже це є проявом формалізованого підходу. Образ є продуктом діяльності головного мозку, тобто це сплав фізіологічних, психофізіологічних та психічних процесів творчої особистості митця, зокрема і диригента. Якщо диригент власною об'єктивністю пригнічує творче сприйняття твору, то він виказує свою «духовну» пустоту та зневагу до творчої діяльності композитора чи автора твору. Деякі диригенти не інтерпретують музичний твір, а лише його відтворюють згідно 3 тим, що написано. Такий підхід є негативним для диригентської діяльності. Робота 3 партитурою у творчості диригента - це не просте читання нот на нотному стані, а проєктування творчих образів, які мають емоційний, естетичний, художній сенс, що зумовлено творчою потребою диригента. Партитура є невичерпним об'єктом пізнання творчого процесу. Вона має безліч творчих трактувань, які віддзеркалюють цілісний авторський текст. Варто зазначити, що диригент-інтерпретатор відшукує у творі ті компоненти, які максимально близькі йому в духовному сенсі. Отже, робота над партитурою супроводжується формуванням власної творчої думки щодо музичного твору шляхом визначення музичної форми й образів.

Формування образу відбувається двома шляхами: інтуїтивно й усвідомлено. Пізнавальний процес музичного твору розвивається водночас двома шляхами: підсвідомо та свідомо, що полегшує формування творчих образів. Музична концепція диригента вимагає виконавської реалізації через творчу діяльність хорового колективу. Провідна роль диригенти, яка базується на образах, є однією зі складових частин, шо доповнюється чітким прогнозуванням музичної ситуації, іiї корегуванням в потрібному напрямі з метою максимального наближення музичної концепції до реального звучання. Творча діяльність хорового колективу - це співпраця диригента й артистів-виконавців згідно з партитурою та музичною концепцією диригента. Таке розуміння диригентської майстерності на сучасному етапі розвитку мистецтва є загальноприйнятим, проте викликає певне запитання: як саме диригент виконує партитуру, коли не має певного уявлення? Уважаємо, що робота 3 хоровим колективом відбувається в основному в умовах підсвідомої психічної діяльності, саме ця сфера містичного забезпечує художньо-змістову функціональність і унікальність хорового дійства [11].

Отже, керівник хорового колективу перебуває в безперервному процесі ендогенних подій, які впливають на моделюючий (концептуальний) інтерпретаційний процес, що надає нового життя музичному твору.

Висновки. Визначення ролі хорового диригента в контексті розвитку сучасного музичного мистецтва показало, що процес підготовки зазначених фахівців зведено до рівня теорії та формального підходу до формування професійних компетентностей. Такий стан речей гальмує фахове зростання особистості, пов'язаний із недостатністю вивчення впливу психофізіологічних важелів на процес накопичення практичного ресурсу. Зазначено, що в наукових дослідженнях, присвячених проблемам формування диригентської майстерності, приділено мало уваги вивченню психофізіологічних аспектів розвитку означеного феномену, а наявний мистецтвознавчий доробок висвітлює локальні питання хормейстерсько-диригентської теорії та практики. Більшість наукових праць мають соціокультурний характер, що не дозволяє визначити сутність професії диригента й особливості формування мануальної техніки. Отже, у пропонованій статті виявлено стан розробленості проблеми формування диригентської майстерності, означено перспективні питання для подальшого наукового дослідження.

\section{СПИСОК ЛІТЕРАТУРИ}

1. Пярт Арво. Беседы, исследования, размышления. Киев : Дух і літера, 2014. 218 с.

2. Бутенко Л. Подготовка дирижеров хора на современном этапе. Специфика проблемы и возможные пути их решения. Музичне мистецтво і культура. Одес а: Друкарський дім, 2009. Вип. 10. С. 313-325.

3. Герасимова-Персидская Н. А. Музыка в слове: аналитические и когнитивные проекции. Науковий вісник Національної музичної академії України імені П.І. Чайковського. Київ, 2003. Вип. 27. C. $3-11$.

4. Герасимова-Персидская Н. Целостность как универсалия и ее проявление в музыке. Науковий вісник Національної музичної академії України імені П.І. Чайковського. Київ, 2005. Вип. 51. С. 3-8.

5. Герасимова-Персидская Н. О восприятии музыки и постижении смысла. Науковий вісник Національної музичної академії України імені П.І. Чайковського. Київ, 2006. Вип. 60. С. 3-8. 
6. Гоменюк С. Игра форм в “Kreuzspiel” К. Штокхаузена. Науковий вісник Національної музичної академії України імені П.І. Чайковського. Київ, 2007. Вип. 61. Кн. 3. С. 161-172.

7. Дмитревская К. Анализ хоровых произведений. Москва : Музыка, 1965. 172 с.

8. Дмитревский Г. Хороведение и управление хором. Москва : Музыка, 1957. 112 с.

9. Дмитриев Л. Основы вокальной методики. Москва : Музыка, 1968. 675 с.

10.Дубинец Е. Знаки звуков. О современной музыкальной нотации. Киев : Гамаюн, 1999. 313 с

11.Ержемский Г. Психология дирижирования. Москва : Музыка, 1988. 78 с.

12.Ефименко А. Пути обновления теории и богослужебной практики католической мессы ХХ ст. Луцк: СНУ им. Леси Украинки, 2011. 404 с.

13. Овод В. Програми педагогічних інститутів. Оркестровий клас : програма для студентів музично-педагогічних факультетів. Київ : РНМК, 1992. 20 с.

14.Ольхов К. Вопросы теории дирижерской техники и обучения хоровых дирижеров. Ленинград : Музыка, 1979. 47 с.

\section{REFERENCES}

1. Arvo, Pyart (2014). Besedy, issledovaniya, razmyshleniya [Conversations, studies, thoughts]. Kyiv: Dukh i Litera [In Russian].

2. Butenko, L. (2009). Podgotovka direzorov khora na sovremennom etape. Spetsifika problem I vozmoznie puti ikh resheniya [Training of choir conductors at the present stage. The specifics of the problem and possible solutions]. In Muzichne mystetstvo I kultura [Music art and culture], 10, 313-325. Odessa: Drukarskiy Dim [In Russian].

3. Gerasimova-Percidskaya, N.A. (2003). Musica v slove: analiticheskie i kognitivnie proektsii [Music in a Word: Analytical and Cognitive Projections]. In Naukoviy visnyk Natsionalnoyi musichnoyi akademii imeni P.I. Chaikovskogo [Scientific Bulletin of the National Music Academy of Ukraine named after P.I. Tchaikovsky], 27, 3-11. Kyiv : NMAU imeni P.I. Chaikovskogo [In Russian].

4. Gerasimova-Percidskaya, N.A. (2005). Tselostnost kak universaliya i yeye proyavleniya v musice [Integrity as a universal and its manifestation in music]. In Naukoviy visnyk Natsionalnoyi musichnoyi akademii imeni P.I. Chaikovskogo [Scientific Bulletin of the National Music Academy of Ukraine named after P.I. Tchaikovsky], 51, 3-8. Kyiv : NMAU imeni P.I. Chaikovskogo [In Russian].

5. Gerasimova-Percidskaya, N.A. (2006). O vospriyatii musici v postizenii smysla [On the perception of music and the comprehension of meaning]. In Naukoviy visnyk Natsionalnoyi musichnoyi akademii imeni P.I. Chaikovskogo [Scientific Bulletin of the National Music Academy of Ukraine named after P. I. Tchaikovsky], 60, 3-8. Kyiv : NMAU imeni P.I. Chaikovskogo [In Russian].

6. Gomenyk, S.G. (2007). Igra slov v "Kreuzspiel" K. Stockhausena [The play of forms in K. Stockhausen's Kreuzspiel]. In Naukoviy visnyk Natsionalnoyi musichnoyi akademii imeni P.I. Chaikovskogo [Scientific Bulletin of the National Music Academy of Ukraine named after P.I. Tchaikovsky], 61 (3), 161-172.

7. Dmitrevckay, K.N. (1965). Analis khorovikh proizvedenii [Analysis of choral works]. Moscow : Musica [In Russian].

8. Dmitrevskii, G. (1957). Khorovedenie i upravlenie khorom [Choral studies and choir management]. Moscow : Musica [In Russian].

9. Dmitriev, L.B. (1968). Osnovi vokalnoi metodiki [Basics of vocal technique]. Moscow : Musica [In Russian].

10.Dubinets, E. (1999). Znaki zvukov. O sovremennoi musikalnoi notatsii [Signs of sounds. About modern musical notation]. Kyiv : Gamaun [In Russian].

11.Ergemskii, G. (1988). Psikhologiya dirizirovaniya [Psychology of conducting]. Moscow : Musica [In Russian].

12.Ephimenko, A.G. (2011). Puti obnovleniya teorii I bogosluzebnoi praktiki katolicheskoi messi XX stoletiya [Ways of updating the theory and liturgical practice of the Catholic Mass of the twentieth century]. Lutsk: SNU im. L. Ukrainki [In Russian].

13.Ovod, V.M. (1992). Programi pedagogichnikh institutive. Orkestrovii klas: programa. [Programs of pedagogical institutes. Orchestra class: program [for students of music and pedagogical faculties]. Kyiv: RNMK [In Ukrainian].

14. Olhov, K. (1979). Voprosi teorii dirizerskoi tekhniki i obucheniya khorovikh dirizerov [Questions of the theory of conducting technique and training of choral conductors]. Leningrad: Musica [In Russian]. 